\title{
Reflections on India's 2018 Guidelines on Cross Border Electricity Trading Vis-a-vis SAARC versus ASEAN
}

Santa Bahadur Pun

Abstract: Despite the 2014 Indo-Nepal Electric Power Trade Agreement and the 2014 SAARC Framework Agreement for Energy Cooperation (Electricity), India issued two Guidelines within two years, one in 2016 and the other in 2018. After discussing the genesis of these two Guidelines, the author attempts to analyze the 2018 Guidelines. With India citing electricity trade as "issues of strategic, national and economic importance", that was couched into "issues of international relations" in the 2018 Guidelines, this explains why the SAARC Framework Agreement for Energy Cooperation (Electricity) has made no headway at all in the last four years. The SAARC region, home of Buddha, Ashok, Akbar etc. may, perhaps, have to look east to the ASEAN on how electricity trading is done there. Electricity, besides being a strategic tool, is also an economic tool that should be used to uplift the quality of life of hundreds of millions of South Asians mired in deep poverty. Unless India takes the initiative akin to ASEAN, SAARC citizens will continue to wallow in that poverty!

Keywords: Electric Power trade agreement, Cross-Border Trade, guidelines, Cross-Border Transmission and Grid Connectivity, India, Nepal

\section{Foreword}

\section{Genesis of India's two Guidelines of 2016 and} 2018

$T^{t}$ is, perhaps, not irrelevant to mull about the genesis of India issuing two Guidelines regarding Cross-Border Trade of Electricity within a span of mere two years. With the creation of her new Ministry of Energy ${ }^{1}$ in 2009, a buoyed Nepal immediately in February 2010 firedoff her Indo-Nepal Power Trade Agreement Draft to India. Twenty-one months later, enquiries in November 2011 about the Draft resulted in Nepal being informed ${ }^{2}$ that 'the MOU would be examined and comments/ observations will be conveyed soon. 'In December 2011, Nepal was assured ${ }^{3}$ that 'India has an open electricity market, which is functioning efficiently for over last five years and Nepal may take advantage of the competitive prices for buying and selling for bulk trade of power between Indian and Nepal....'Further prodding resulted in India informing ${ }^{4} \mathrm{Nepal}$ in January 2013 'the process would take little more time ${ }^{5}$ in spite of continuous follow up because the proposed MOU is a new idea to the concerned agencies of Government of India.'

After a protracted four-year bitter hiatus, India surprisingly proposed instead an Indo-Nepal Power Sector Agreement draft which was a clear indication of the Delhi mandarins' intention to choreograph Nepal's power sector, in effect Nepal's entire water resources. Nepal's Energy Ministry ${ }^{6}$ was in a quandary on how to move forward. Fortunately, this was solved by India's 2014 general election that brought in a change of guard at New Delhi. With Bharatiya Janata Party's resounding victory, Narendra Modi became India's 15th Prime Minister on May 26, 2014. Without consulting his powerful South Block mandarins, Modi, embracing his "neighborhood first" policy, invited all the Prime Ministers and Presidents of the SAARC countries for his inauguration ceremony at New Delhi. Prime Minister Modi immediately visited the neighboring countries, including Nepal where the rapturous Nepalese parliament gave him a memorable and thunderous welcome. Contrary to South Block's bilateralism policy, Prime
Minister Modi's 'neighborhood first' vision compelled the mandarins to initial both the Indo-Nepal Electric Power Trade, Cross-Border Transmission and Grid Connectivity and the SAARC Framework Agreement for Energy Cooperation (Electricity) (Afghanistan, Bangladesh, Bhutan, India, the Maldives, Nepal, Pakistan and Sri Lanka) at Kathmandu on October 21, 2014 and November 27, 2014 respectively.

\section{Indo-Nepal 2014 Electric Power Trade}

The October 2014 Indo-Nepal Electric Power 1 Trade, Cross-Border Transmission and Grid Connectivity agreement has the following two important "non-discriminatory access" clauses on crossborder power trading:

\section{ARTICLE-II}

(b) The Parties shall allow non-discriminatory access to the cross-border interconnection(s) for all authorized/licensed participants in the common electricity market.

\section{ARTICLE-IV}

(b) The Parties shall allow the authorized/licensed electricity producers/buyers/traders of each country to engage in cross-border electricity trading, including that through Power Exchanges, and to seek cross-border transmission access as per the laws of the respective country.

\section{SAARC Framework Agreement for Electricity Trade \\ Similarly, while the preamble of the November 2014SAARC Framework Agreement for Energy Cooperation (Electricity) states:}

Recognizing the importance of electricity in promoting economic growth and improving the quality of life; Realizing the common benefits of cross border electricity exchanges and trade among the SAARC Member States leading to optimal utilization of regional electricity generating resources, enhanced grid security, and electricity trade arising from diversity in peak demand and seasonal variations; the 
other relevant Articles clearly stresses:

\section{Article 1 \\ Buying and Selling Entities}

Buying and Selling Entities means any authorized public or private power producer, power utility, trading company, transmission utility, distribution company, or any other institution established and registered under the laws of any one of the Member States having permission of buying and selling of electricity within and outside the country in which it is registered.

\section{Article 12}

Transmission Access

Member States shall, for the purpose of crossborder trade, enable non-discriminatory access to the respective transmission grids as per the applicable laws, rules, regulations and applicable intergovernmental bilateral trade agreements.

\section{Article 13}

\section{Facilitating Buying and Selling Entities}

Member States shall enable Buying and Selling Entities to engage in cross-border electricity trading subject to the laws and regulations of the concerned Member States.

\section{India's 2016 Guidelines}

It took only two years for the powerful mandarins at New Delhi's South Block to undo what Prime Minister Modi's "neighborhood first" policy attempted to do. Citing electricity trade involved "issues of strategic, national and economic importance", India issued the "Guidelines on Cross Border Trade of Electricity "on December 5, 2016 with the following more salient clauses:

5.2.1 ........, participating entities (Participating Entity(ies)) complying with following conditions shall be eligible to participate in cross border trade of electricity after obtaining one-time approval from the Designated Authority:

\section{a. Imports of electricity by Indian entities from} Generation projects located outside India and owned or funded by Government of India or by Indian Public Sector Units or by private companies with $51 \%$ or more Indian entity (entities) ownership;

5.2.2 Any other participating entity shall be eligible to participate in cross border trade of electricity after obtaining approval of the Designated Authority on case to case basis.

This translated to, while export of hydropower from Nepal to India by Indian government owned entities (Satluj Jal Vidhyut Nigam's 900 MW Arun III) or private companies with $51 \%$ or more Indian ownership (GMR's 9oo MW Upper Karnali) will need a "one-time approval", all other entities were to be examined "on a case to case basis" and only then granted approval. This 2016 Guideline was clearly against the spirit envisioned by the 2014 Indo-Nepal Power Trade Agreement and SAARC Framework Agreement for Energy Cooperation (Electricity). Observers believe the Guideline was specifically directed towards Nepal fearing the increasing investment in hydropower by the financially muscular Chinese companies. The Indian elephant is extremely shy of the Chinese dragon lurking across her border in Nepal. The government of Nepal officially protested and even Bangladesh's Prime Minister Hasina Begum in April 2017 during her official visit requested India to 'facilitate' the Bangladesh-Nepal electricity trade over India's $18 \mathrm{~km}$ stretch.

\section{India's 2018 Guidelines}

Hence, the dexterous South Block mandarins cobbled up the second December 18, 2018 "Guidelines for Import/Export (Cross Border) of Electricity 2018" repealing the December 5, 2016 Guidelines on Cross Border Trade of Electricity.

Without fully delving into the depth of the second 2018 Guidelines, there were, as usual, jubilations in Nepal. While, The Himalayan Times reported7 "Indian Government amends Electricity Regulation - Nepali Hydel Developers can Export Power to Third Countries", Kathmandu Post front-lined ${ }^{8}$ "India Relaxes Cross Border Power Trading Guidelines - Move opens the Way for Nepal to Export Surplus Electricity to Bangladesh via Indian Transmission Lines."The euphoric President of the powerful Independent Power Producers' Association Nepal (IPPAN), Shailendra Guragain, did not mince words saying9 "It was the result of our continuous lobbying, negotiations and also pressure from neighboring countries for access to the market of the South Asian giant." Dinesh Kumar Ghimire, Joint Secretary at the Ministry of Energy, Water Resources and Irrigation, called the new Guidelines ${ }^{10}$ "more progressive than the earlier one" and expressed happiness terming it "...a good news for foreign investors who want to invest in hydropower in Nepal......" Even Semana Dahal, a lawyer advising the Government of Nepal, said" "This will foster power trade between Nepal and Bangladesh, giving opportunity to the former to export surplus electricity that is on the track to generate within a few years." Mr. Dahal is not incorrect in stating that within a few years Nepal is expected to have wet season surplus energy. But he is incorrect in assuming that Nepal's surplus energy will foster power trade with Bangladesh. In the immediate aftermath of India's December 18, 2018 Guidelines that opened up third party access through Indian territories to Nepal's surplus power, the December 28, 2018 Kathmandu Post reported" "Nepal and India agree on Energy Banking." Observers are quite surprised by this IndoNepal Energy Banking deal, initialed in utmost haste, at a time when third-party access had just opened up. Energy Banking, even within Indian States, is in its very preliminary infancy stage. It is surprising why Nepal did not wait to assess the other available options for her wet season surplus energy.

If one carefully peruses India's 2018 Guidelines, the basic tenets of her 2016 Guidelines are all intact, embedded and couched in bureaucratic and legal jargons. The following are some of the more notable notes of the 2018 Guideline: 
3.1 The import/export of electricity......consistent with the provisions of the prevailing laws in the respective country(ies).... Provided that in the case of tripartite agreements, the cross border trade of electricity across India shall be allowed under the overall framework of bilateral agreements signed between the Government of India and .....

Despite the November 2014 SAARC Framework Agreement for Energy Cooperation (Electricity), one gets the strong flavor of India sticking to bilateralism in the 2018 Guideline. Bilateralism has always been the modus operandi of the South Block mandarins.

4.2 .....appoint a Designated Authority for facilitating the process of approval and laying down the procedure for import/export of electricity....

4.4 ....Any entity proposing to Import or Export electricity may do so only after taking the approval of the Designated Authority.

4.6 Considering the fact that import/export of electricity involves issues of international relations; the Designated Authority will grant approval or otherwise only after taking concurrence of Govt. of India.

Firstly, this "issues of international relations" is merely a continuation of the 2016 Guideline's "Considering that electricity trade shall be involving issues of strategic, national and economic importance,...", and secondly even the Government of India's Designated Authority will grant approval or otherwise only after taking concurrence of Govt. of India - that is, the Govt. of India's Designated Authority will have to await the fait accompli of another Govt. of India at South Block!

6.1 The Designated Authority shall grant approval for export/import of electricity only after taking into account the generation capacity (as available) and the demand. Imports may normally be permitted only when the demand exceeds generation....... However, Govt. of India reserves the right to import/export electricity from/to neighboring countries for reasons of larger policy interests.

Thus, export of electricity to India is "only when the demand [in India] exceeds [her] generation". This could well lead to the Load Forecast fracas that Nepal had to undergo between NEA's so-called pessimistic and IPPAN's optimistic load forecast that ultimately had to be intervened by the National Planning Commission. Nepal should also note: "Govt. of India reserves the right.....for reasons of larger policy interests”.

6.2 The Designated Authority shall consider the application for approval of participating Entity (ies) only after the receipt of the equity pattern of ownership of the said Entity (ies).....

This is an intelligent way of catching a person's ear from the other way around - rephrasing merely the 2016 Guideline's “....owned or funded by Government of India or by Indian Public Sector Units or by private companies with $51 \%$ or more Indian entity (entities) ownership....". Like the 2016 Guideline, the 2018 Guideline also embodies that inherent Indian fear of the Chinese dragons lurking in Nepal's hydropower sector.

7.1.1 The tariff for import of electricity by the Indian Entity (ies) as per sub-clause 5.1 shall be determined, through a process of competitive bidding as per Tariff Policy of India or through mutual agreement. Provided that in case of hydro projects, the tariff may be determined by CERC as per its Regulations...

This "Provided that in case of hydro projects" is tactically directed towards Nepal's hydropower export whose tariff "may be" determined by Central Electricity Regulatory Commission (CERC). Nepal's muscular IPPAN had had its way in Nepal: reverting the Take and Pay power purchase agreements to Take or Pay, irrespective of hydro-project sites a flat tariff based on whether they are storages, run-of-river or run-ofriver peaking and capacity of the project to be based on $Q 40$ flows. IPPAN, perpetually eyeing the Indian market, will now have to undergo the rigors of India's regulatory mechanisms. Time and only time will tell whether IPPAN's rapture will continue unabated when it faces the above mentioned 'safety valves" in India's 2018 Guideline on Cross Border Power Trade. The proof of the pudding for IPPAN will always be in the eating!

\section{Electricity Trade among ASEANs}

After the above ramble on Energy Cooperation (Electricity) among the SAARC nations, a small peep into how electricity trading is conducted among the Association of South East Nations (ASEAN), in particular Laos, is illuminating. Laos, like Nepal, is landlocked and hydropower rich. With the global liberalization of power sector, Laos and Thailand signed an MOU in 1993 to trade $1500 \mathrm{MW}$ of cross border power. This power trade MOU has by 2018 been successively increased to 9,000 MW. Such a 9,000 MW MOU has attracted foreign hydropower investors to Laos as Thailand has guaranteed to buy that quantum of Laotian power. In stark contrast to SAARC, this is the ASEAN model of cross border electricity trading. Attached at the end of this article is an old 2008 table indicating 2,500 MW of hydropower projects under construction in Laos with investments from France, Norway, USA, China, Thailand, Vietnam etc. both for domestic and export purposes. To be noted is the investors' equity percentage in the project that India's 2016 and 2018 Guidelines are so sensitive about. India's 2018 Guideline indicates that the SAARC countries have a long way to go to replicate the ASEAN model of cross border electricity trading.

Recently, from January 1, 2018 Laos began supplying 100 megawatts of hydroelectric power to far-off Malaysia through Thailand's long grid. The three utilities involved are Electricite du Laos (EDL), Electricity Generating Authority of Thailand (EGAT) and Malaysia's Tenaga Nasional. Malaysia is keen to increase the share of renewable energy in her fuel mix that is currently dominated by coal and gas. At SAARC, Bangladesh, like Malaysia, is equally keen to diversify her coal/gas dominated fuel mix with hydropower from Bhutan and Nepal. But so far as the elephant in the middle continues 
to believe "electricity trade as a strategic issue", Nepal/ Bhutan cannot replicate the business that Laos and Malaysia are conducting. The Energy Purchase and Wheeling Agreement (EPWA) govern the obligations of the parties in the selling, wheeling and purchase of energy from EDL/Laos via EGAT/Thailand (the wheeler) to TNB/Malaysia for the two-year period. The purchase price has not been disclosed. Once the agreement ends, the involved parties will negotiate again on future energy trading. This is the first tripartite project of its kind among the 10 members of the Association of Southeast Asian Nations (ASEAN) that identified 16 projects for implementation through $\$ 6$ billion of investment under the ASEAN Power Grid initiative. These projects were

\begin{tabular}{|c|c|c|c|c|c|c|}
\hline Name & Location & Year* & $\begin{array}{c}\text { Capacity } \\
\text { (MW) }\end{array}$ & $\begin{array}{c}\begin{array}{c}\text { Genera- } \\
\text { tion* }\end{array} \\
(\text { GWh) }\end{array}$ & Market & Ownership \\
\hline $\begin{array}{l}\text { Nam } \\
\text { Theun } 2\end{array}$ & $\begin{array}{l}\text { Kham- } \\
\text { mouane/ } \\
\text { Bo- } \\
\text { likhamxay }\end{array}$ & 2009 & 1,088 & 5,936 & $\begin{array}{l}95 \% \text { Export } \\
\text { (Thailand) }\end{array}$ & $\begin{array}{l}\text { LHSE (Lao PDR) } 25 \% \\
\text { EDF (France) } 35 \% \\
\text { EGCO (Thailand) } 15 \% \\
\text { ITD (Thailand) } 15 \%\end{array}$ \\
\hline Xeset 2 & Saravane & 2009 & 76 & 309 & $\begin{array}{l}\text { 20\% Export } \\
\text { (Thailand) }\end{array}$ & EdL (Laos) \\
\hline $\begin{array}{l}\text { Nam } \\
\text { Nhone }\end{array}$ & Bokeo & 2009 & 3.5 & - & Domestic & EdL (Laos) \\
\hline $\begin{array}{l}\text { Nam } \\
\text { Lik1-2 }\end{array}$ & Vientiane & 2010 & 100 & 435 & Domestic & $\begin{array}{c}\text { EdL } 10 \% \\
\text { China International Water and } \\
\text { Electric Corp } 90 \%\end{array}$ \\
\hline Tatsalen & $\begin{array}{c}\text { Savanna- } \\
\text { khet }\end{array}$ & 2010 & 3.2 & - & Domestic & $\begin{array}{c}\text { SIC Manufacturer (Thailand) } \\
100 \%\end{array}$ \\
\hline Xekaman 3 & Sekong & 2011 & 250 & 977 & $\begin{array}{l}90 \% \text { Export } \\
\text { (Vietnam) }\end{array}$ & $\begin{array}{c}\text { EdL 15\% } \\
\text { Viet-Lao Power Investment } \\
\text { and } \\
\text { Development Joint Stock 85\% }\end{array}$ \\
\hline $\begin{array}{l}\text { Nam } \\
\text { Ngum } 5\end{array}$ & $\begin{array}{l}\text { Vientiane/ } \\
\text { Xiangk- } \\
\text { ouang }\end{array}$ & 2011 & 120 & 507 & Domestic & $\begin{array}{c}\text { EdL } 15 \% \\
\text { Sinohydro } 85 \%\end{array}$ \\
\hline $\begin{array}{l}\text { Nam } \\
\text { Ngum } 2\end{array}$ & Vientiane & 2013 & 615 & 2,300 & $\begin{array}{c}\text { 100\% Export } \\
\text { (Thailand) }\end{array}$ & $\begin{array}{c}\text { EdL 25\% } \\
\text { Ch. KanchangPLC 25\% } \\
\text { Bangkok Expressway PLC } \\
12.50 \% \\
\text { Shlapak Development Com- } \\
\text { pany (USA) 4\% } \\
\text { PT Construction \& Irrigation } \\
\text { Co. Ltd } \\
\text { (Lao PDR) 4\% } \\
\text { Team Consulting Engineer- } \\
\text { ing and } \\
\text { Management Co.. Ltd (Thai- } \\
\text { land) 1\% }\end{array}$ \\
\hline $\begin{array}{l}\text { Theun- } \\
\text { Hinboun } \\
\text { Expansion }\end{array}$ & $\begin{array}{c}\text { Bo- } \\
\text { likhamxay }\end{array}$ & 2012 & $220+60$ & - & $\begin{array}{l}88 \% \text { Export } \\
\text { (Thailand) }\end{array}$ & $\begin{array}{c}\text { EdL 60\% } \\
\text { Nordic Group (Norway) 20\% } \\
\text { MDX (Thailand) } 20 \%\end{array}$ \\
\hline TOTAL & & & 2,536 & 10,464 & & \\
\hline
\end{tabular}

designed to boost energy security and meet future demand of ASEAN.

\section{Final Words}

The eight SAARC member countries (Afghanistan, B angladesh, Bhutan, India, the Maldives, Nepal, Pakistan and Sri Lanka) did sign the SAARC Framework Agreement for Energy Cooperation (Electricity) in Kathmandu on November 27, 2014. Unlike the ASEAN model of regional electricity trading, the SAARC model is, however, entangled by India's basic tenet that regional electricity trade involves "issues of strategic, national and e c o n o m i c importance."

India exercised this tenet over a decade ago when the USAID initiated the well-meaning Four Border Project (India, Bangladesh, Nepal and Bhutan) through the South Asia Regional Energy Initiative

Table 1: Power Projects Under Construction in Lao PDR (SAREI). SAREI initially envisaged cross border regional electricity trading to the tune of only about 100 MW. This was essentially a confidence building measure to kick-start regional electricity trading. Though Bangladesh, Bhutan and Nepal were all very keen, India, the kingpin linking all the four borders, not only evinced total disinterest but displeasure as well. Despite being initiated by the superpower USA, the project met its natural death as the regional superpower had other ideas. India then initiated another kind of Four Border Project that is currently operating in that region. The kingpin, India, imports around 1,500 MW of hydropower 
from Bhutan at dirt-cheap rate. While 500 MW is sold to Nepal at a mutually accepted rate, the rest of it goes to churn Bangladesh's booming economy also at mutually accepted rates. USAID's SAREI project had envisaged regional electricity trading where Bhutan could sell her power directly to Nepal and Bangladesh - or for that matter develop Nepal's hydropower in the Kosi basin for export to Bangladesh. But as spelled out by India's 2016 Guideline "electricity trade involved issues of strategic, national and economic importance", India opted to play her own kind of regional role- that usual modus operandi of bilateralism, allowing her to part away with a sizable chunk of the mutually accepted tariff!

This is not exactly what Article 12 of the November 2014 SAARC Framework Agreement for Energy Cooperation (Electricity) states:

Member States shall, for the purpose of crossborder trade, enable non-discriminatory access to the respective transmission grids...

And unless the SAARC countries trade cross border electricity in the manner that ASEAN's Laos and Malaysia are trading, we, in the SAARC region, will continue to grovel in poverty!

\section{S.B. Pun is Former Managing Director of Nepal} Electricity Authority and in his later years served as an Officer on Special Duty at Ministry of Water Resources, Government of Nepal. He writes on energy and water issues.

\section{Corresponding address: santapun@ntc.net.np}

\section{footnotes}

1. In 2009 the Government of Prime Minister Madhav Kumar Nepal sent the Ministry of Water Resources to thy kingdom come by creating the two Ministries of Energy and Irrigation so that the coalition government of CPN-UML and Nepali Congress could share the State's loaves and fishes more.
2. 6th Joint Committee on Water Resources (JCWR) meeting of November 24-25, 2011 at New Delhi.

3. 10th Power Exchange Committee (PEC) meeting of December 14-15, 2011 at New Delhi.

4. 7th Joint Committee on Water Resources (JCWR) meeting of January 24-25, 2013 at Kathmandu.

5. Various reasons are alluded to, for this 'little more time' of over two and half years for India's Ministry of External Affairs to 'examine and comments/observations...conveyed soon' to Nepal's Draft MOU on Cross-Border Interconnection for Electric Power Trade. The most plausible reason is that India's MEA was miffed with Nepal's proposed Draft MOU. Reliable sources indicate that this MOU was drafted with the assistance of international consultants provided by the World Bank. This, hence, rubbed India's MEA the other way!

6. This credit goes to Dipak Gyawali, former Water Resources Minister, for his advice about India's proposed Draft to the then Energy Minister Radha Gyawali from the CPN-UML party.

7. The Himalayan Times - Business, December 24, 2018.

8. The Kathmandu Post - Money, December 23, 2018.

9. Ibid Footnote 7.

10.Ibid Footnote 7.

\section{Ibid Footnote 8.}

12.The Kathmandu Post, December 28, 2018 where NEA Managing Director, Kulman Ghising, "without sharing the details of the draft", is reported as saying, "This agreement is a milestone in the country's energy sector as it will secure the market for the surplus energy we are on track to produce within a few years."

13.The tariff that India buys from Bhutan is slightly over 2 IRs per $\mathrm{kWh}$ while the tariff that India sells to Nepal and Bangladesh is around 5.60 IRs per kWh.

14. The Kathmandu Post, December 28, 2018 where NEA Managing Director, Kulman Ghising, "without sharing the details of the draft", is reported as saying, "This agreement is a milestone in the country's energy sector as it will secure the market for the surplus energy we are on track to produce within a few years." 